\title{
Evaluation of the Users of Edmodo Content Management System in Secondary Education
}

\author{
Özge Beyatlı ${ }^{1 *}$, Fahriye Altinay ${ }^{1}$, Zehra Altinay ${ }^{1}$ \\ ${ }^{1}$ Near East University, Nicosia, CYPRUS
}

Received 28 January 2018 - Revised 1 May 2018 - Accepted 6 May 2018

\begin{abstract}
This study aimed to investigate teachers' views about the effectiveness of users of Edmodo Content Management Systems in secondary education. Teachers from Near East College in Fall of 2016-2017 academic year participated in this study. Methodologically, qualitative research was carried out with open-ended interview questions prepared for the participants. Teachers' views were reached through the analysis of the data. The analysis results showed that the teachers already knew about Edmodo Content-Management System, but they were ineffective in practising it. Therefore, the findings reflected the need for educating the teachers in the system.
\end{abstract}

Keywords: Edmodo, Content Management System, imaginary learning environments

\section{INTRODUCTION}

Technology has always been an important aspect of education through its support of teacher and students in removing the barriers and limitations to learning development. Blumenfeld et al. (1991) argued that technology can sustain student motivation and support student learning and doing during the various phases of projects, can supplement and complement teachers' instructional and managerial roles, relieving teachers of some of the complexities of implementing projects.

The primary purpose of education today, is to raise individuals with skills to integrate IT into learning and teaching, access information easily, develop self-learning, be able to do research, and be creative. Karaman, Yıldırım, and Kaban (2008) stress that the use of Web. 2.0 tools in education helps more effective learning, has the responsibility for learning, collaborates through group-work and develops critical thinking skills. It also has advantages for the students, such as; sharing pictures or videos, on-line environments and private mailing. These advantages create tendency to use Web. 2.0 technologies in education (Karal \& Karakoç, 2010). Besides the advantages, social networks have some disadvantages too, such as, improper advertising, internet perverts, cyberbullying, which make teachers and families use the internet more carefully and due to such inconveniences, some schools tend to ban the use of social web sites (Harshman \& Maguth, 2013) and develop environments that can only be used for education purposes.

We often face social learning environments, which are the essentials of education to raise creative individuals with the skills to access information easily and do research. According to Thongmag (2013), social learning environments facilitate educational interaction between teacher and student and among students. They also involve students in an active learning environment, facilitate collaboration in group projects, and provide easy sharing of course grades. The importance of on-line social web sites is the profile pages, on-line environments, private mailings, and their being open for everybody for interpretation (Rigby, 2008). For example the Stanford Mobile Inquiry-based Learning Environment (SMILE) combines a mobile-based question application for students with a management application for teachers. The classroom management software allows students to share, respond, and rate questions on criteria such as creativity or depth of analysis (Buckner \& Kim, 2013).

Edmodo, for Jarc (2010), Kongchan (2008), Balasubramanian, Jaykumar,and Fukey (2014), is a social web platform in which teachers can set an on-line classroom environment to easily interact with their students in safety and independent of time and place, and without costs. Developed for educational purposes in 2008, Edmodo offers free and secure software that supports varied education and teachers can create groups that students can join after

(C) 2018 by the authors; licensee Modestum Ltd., UK. This article is an open access article distributed under the terms and conditions of the Creative Commons Attribution License (http://creativecommons.org/licenses/by/4.0/). \ozge_beyatli@hotmail.com (*Correspondence) $\square$ fahriye.altinay@neu.edu.tr $\square$ zehra.altinay@neu.edu.tr 


\section{Contribution of this paper to the literature}

- This study has a vision to raise teacher awareness of the importance of the use of social learning environments in education.

- This research will contribute to the literature on the application of Edmodo platform.

- Teachers in the secondary education have a high perception of Edmodo Content Management System, but they lack the sufficient skills in applying it.

being invited by the teacher or by entering a group code (Végh, Nagy, Zsigmont, \& Elbert, 2017). Through this platform, the teachers can share videos, pictures, office files, questionnaires, interactive quizzes, links and embed codes with their students (Doğan, 2012). Edmodo has provided great facilities in terms of education supported by Turkish language from 2013 onwards. The number of users of Edmodo is increasing day-by-day because it provides a wide range of collaboration among teachers.

The system's contribution to education;

- The use of technology contributes to learning

- The use of technology facilitates learning

- The use of technology raises awareness of its facilities it provides in education

In this study needs-analysis was done to specify the needs to define the effectiveness of the users of Edmodo Content Management System. In this respect, the following questions were asked;

1. What is the level of participant perception of Edmodo Content Management System application in language teaching?

2. What is the level of participant perception of_Edmodo Content Management System?

3. What is the level of participant perception of Edmodo application in general?

\section{METHODOLOGY}

\section{Research Method}

A qualitative research method was applied in this study. According to Yıldırım and Şimşek (2006), a qualitative research is an approach to understand the participant views and through induction to describe events and facts in their natural environments.

\section{The Participants}

Teachers from Near East College, in the 2016-2017 academic year, participated in this study.

\section{Data Collection Tools}

Three open-ended questions were prepared by the researcher as data collection tools. The questions were prepared after an overview of the literature to specify problems and expectations. The questionnaire were prepared in the light of the views by two experts in the field, one language expert, and one analyst. The questions were finalized in accordance with the feedbacks of the experts. While preparing the open-ended questionnaire utmost care was taken on the principles; to ask questions without multi-dimensions, questions being clear and understandable, and existence of alternative questions (Yıldırım \& Şimşek, 2013).

\section{Data Collection Procedure}

In order to define the needs in the effectiveness of the users of Edmodo Content Management System in language teaching in secondary education, unstructured interview forms were given to the participants.

\section{Data Analysis}

Out of 221 participants only 138 were evaluated within the scope of the research. The evaluation of the data was done in the light of the participant teachers' views. 


\section{FINDINGS}

\section{Participant views about Edmodo contribution to Language Teaching}

The findings of this research indicate that many participants have positive views about Edmodo contribution to language teaching. P4 stated that, "Students who have difficulties in expressing themselves in physical environments, can overcome such difficulties in social environments and this helps them develop their language skills". "I totally agree that, connections and sharing all around the world will contribute to language teaching".

P78 supported this and added, "I say it contributes. It helps teacher development and motivates students." P21 said "I think it will be quite useful because several activities can be done in different languages". "Due to the environment where there is interaction and students with different languages, they have the opportunity to exchange information" explained by P59.

Some participants disagree with these positive views and stress that Edmodo does not contribute to language teaching.

P70 said that, "Edmodo does not contribute to language teaching". A similar view was from P67, who said, "Edmodo does not contribute much to language teaching". When the views of the participants with perception for the contribution of Edmodo use in language teaching analysed, positive contributions can be noted for language teaching because in an Edmodo environment the students are always in interaction and they get in contact with students from other countries.

\section{Participant views about Edmodo Content Management System}

From the data obtained in this research, it has been noted that many participants do not have sufficient knowledge about Edmodo Content Management System. P40 explained views saying, "Both the teachers and students should be well informed about this program". "I do not have any suggestions because I rarely use it" said P30. On the other hand, participants who knew about the Edmodo Content Management System raised positive views. P3 expressed views saying, "Applications such as, Content Management System, sharing information through several systems, gathering exams and homework in a common page, and following performance are of great use". "It is quite a useful system because of its being a Content Management System and as long as it is practised, performance increases consequently" added P21.

P28 raised views saying, "I do not believe in any of such methods. Every kind of technology use, causes inattentiveness among students"

P17 expressed dissatisfaction saying, "Incorrect and useless information can be shared. Therefore, it is not very reliable"

The participant teachers in this study did not have sufficient perception about Edmodo content system and thus many of them responded negatively which indicate that the use of technology in education was wrong for them.

\section{Participant views about deficiencies in Edmodo applications}

The study results indicate that, many of the participants expressed worries as them not being well informed about the discrepancies. As P33 stated, "I do not use Edmodo Content Management System, so I have no idea about the discrepancies". "I do not know anything about Edmodo applications" said P21. The reason for the lack of information about the system is assumed to have emerged from Edmodo's being a new application.

P17 explained saying, "I do not use it so often so that I can notice what is wrong or right"

P34 admitted saying, "I have no idea because I do not use it"

When the participants' perception of what is wrong and right about Edmodo use was considered, it is clear that they did not know much about Edmodo because they did not use it.

\section{DISCUSSION}

The findings indicated positive views in terms of the contribution of Edmodo to language teaching. Brady, Holcomb, and Smith (2010) points to the fact that educational social- web sites give the opportunity to teachers and students to use these webs for educational purposes. When literature is examined, it is noted that Edmodo is a new application and there are limited studies done on it. In the studies conducted, it is stated that Edmodo provides a safe and suitable environment serving educational activities (Çankaya, Durak, \& Yunkul, 2014; Kongehan, 2008; Sanders, 2012). Echols and Tipton (2012) argue that, Edmodo is a social platform where information can be shared in safety, examinations can be given, homework can be assigned, grading can be followed, and questionnaires can be prepared. Research by Fardoun et al. (2012) support the use of social networking as an educational tool and discuss Edmodo as an educative online social network. The participant teachers had views indicating that students who have difficulties expressing themselves in physical environments, find it easier to do so in social environments where they improve their language skills. Ajjan and Hartshorn (2008) argue that such applications develop student 
writing skills, enhance learning, facilitate communication and raise motivation and involve students in the learning process. Another support came from Sirakaya (2014) who stressed that students who use Edmodo Content Management System can follow the courses outdoors and they do not lose interest in the courses. According to a study by Sanders (2012), this is in parallel with students' feeling of responsibility for their self-learning.

The findings in this research indicate that teachers lack sufficient information about Edmodo Content System and thus they need training in the application. In a similar research, the teachers and students who use Facebook as a social platform can understand the function of Edmodo and became able to use it in a minimum period of time (Shockney, 2013).

It was found out in the end of this research that some of the participant teachers did not have sufficient information about Edmodo Content System and are worried about not being able to use it. In a similar study, it is stressed that teachers can be members of Edmodo groups and contribute both to professional and personal development (Alemdağ, 2013).

\section{CONCLUSION}

It has been found out in this research that, teachers in the secondary education have a high perception of Edmodo Content Management System, but they lack the sufficient skills in applying it. The reason for this is related to the new application of the system in schools. Therefore, seminars and trainings should be organized to raise teacher awareness of the subject question.

\section{REFERENCES}

Ajjan, H., \& Hartshorne, R. (2008). Investigating faculty decisions to adopt Web 2.0 technologies: Theory and empirical tests. The Internet and Higher Education, 11(2), 71-80. https:/ / doi.org/10.1016/j.iheduc.2008.05.002

Alemdağ, E. (2013), Edmodo: Eğitsel bie çevirimiçi sosyal öğrenme ortamı. In XVIII. Türkiye'de İnternet Konferansı. İstanbul Üniversitesi, İstanbul.

Balasubramanian, K., Jaykumar, V., \& Fukey, L. N. (2014). A study on student preference towards the use of edmodo as a learning platform to create responsible learning environment. Procedia-Social and Behavioral Sciences, 144, 416-422. https:/ / doi.org/10.1016/j.sbspro.2014.07.311

Blumenfeld, P. C., Soloway, E., Marx, R. W., Krajcik, J. S., Guzdial, M., \& Palincsar, A. (1991). Motivating projectbased learning: Sustaining the doing, supporting the learning. Educational psychologist, 26(3-4), 369-398. https:/ / doi.org/10.1080/00461520.1991.9653139

Brady, K. P., Holcomb, L. B., \& Smith, B. V. (2010). The use of alternative social networking sites in higher educational settings: A case study of the e-learning benefits of ning in education. Journal of Interactive Online Learning, 9(2), 151-170.

Buckner, E., \& Kim, P. (2014). Integrating technology and pedagogy for inquiry-based learning: The Stanford Mobile Inquiry-based Learning Environment (SMILE). Prospects, 44(1), 99-118. https:/ / doi.org/10.1007/s11125-013-9269-7

Çankaya, S., Durak, G., \& Yunkul, E. (2014). Using educational social networking sites in higher education: edmodo through the lenses of undergraduate students. European Journal of Education Technology, 1(1).

Doğan, M. A. (2012). Egitsel Bir Sosyal Ag Uygulaması: EDMODO (in Turkish). Retrieved from http:// prezi.com/brahi-uom5fc/egitsel-bir-sosyal-ag-uygulamas-edmodo/

Echols, V., \& Tipton, T. (2012). Byod and the freshman orientation experience - creating an exciting, hi-tech event. Texas Study Magazine.

Fardoun, H. M., Alghazzawi, D. M., López, S. R., Penichet, V. M., \& Gallud, J. A. (2012). Online social networks impact in secondary education. In International Workshop on Evidence-Based Technology Enhanced Learning (pp. 37-45). Springer, Berlin, Heidelberg. https:// doi.org/10.1007/978-3-642-28801-2_5

Harshman, J. M., \& Maguth, B. M. (2013). Social networking and the social studies for citizenship education. Journal of the Research Center for Educational Technology, 9(1), 192-201.

Jarc, J. (2010). Edmodo-a free, web2. 0 classroom management tool.

Karal, H., \& Kokoç, M. (2010). Üniversite öğrencilerinin sosyal ağ siteleri kullanım amaçlarını belirlemeye yönelik bir ölçek geliştirme çalışması (in Turkish). Turkish Journal of Computer and Mathematics Education (TURCOMAT), 1(3).

Karaman, S., Yıldırım, S., \& Kaban, A. (2008). Öğrenme 2.0 yaygınlaşıyor: Web 2.0 uygulamalarının eğitimde kullanımına ilişkin araştırmalar ve sonuçları (in Turkish). XIII. Türkiye'de İnternet Konferansı Bildirileri. 
Kongchan, C. (2008). How a non-digital-native teacher makes use of edmodo. In 5th International Conference ICT for Language Learning. Florence.

Rigby, B. (2008). Mobilizing Generation 2.0 A Practical Guide to Using Web 2.0 Technologies to Recruit, Organize, and Engage Youth. Jossey-Bass, San Francisco, USA.

Sanders, K. S. (2012). An Examination of the Academic Networking Site Edmodo on Student Engagement and Responsible Learning (Unpublished Doctoral Dissertation).

Sırakaya, M. (2014). Öğretmen Adaylarının Edmodo Hakkındaki Görüşleri (in Turkish). http:/ /www.researchgate.net/publication/276354138_retmen_Adaylarnn_Edmodo_Hakkndaki_Grleri_T eacher_Candidates\%27_Views_On_Edmodo

Shockney, R. (2013). Measuring Effectiveness of a Social Networking Site in a Middle School (Masters Thesis), California State University, California.

Thongmak, M. (2013). Social network system in classroom: Antecedents of edmodo adoption. Journal of e-Learning and Higher Education, Vol. 2013 (2013), Article ID 657749. https:/ / doi.org/10.5171/2013.657749

Végh, V., Nagy, Z. B., Zsigmond, C., \& Elbert, G. (2017). The Effects of Using Edmodo in Biology Education on Students' attitudes towards Biology and Ict. Problems of Education in the 21st Century, 75(5).

Yıldırım, A., \& Şimşek, H. (2006). Sosyal Bilimlerde Nitel Araştırma Yöntemleri (in Turkish) (6. Ed.) Ankara: Seçkin Yayıncilik.

Yıldırım, A., \& Şimşek, H. (2013). Sosyal Bilimlerde Nitel Araştırma Yöntemleri (in Turkish) (9. Ed.) Ankara: Seçkin Yayınevi.

\section{http://www.ejmste.com}

